\title{
Ipsilateral shoulder pain after thoracic surgery procedures under general and regional anesthesia - a retrospective observational study
}

\author{
Hanna Misiołek ${ }^{1}$, Jacek Karpe ${ }^{1}$, Maja Copik ${ }^{1}$, Adrian Marcinkowski ${ }^{1}$, Aleksandra Jastrzębska ${ }^{2}$, Anna Szelka², \\ Adrianna Czarnożycka², Michał Długaszek ${ }^{2}$
}

${ }^{1}$ Katedra Anestezjologii, Intensywnej Terapii i Medycyny Ratunkowej w Zabrzu, Śląski Uniwersytet Medyczny w Katowicach

2Studenckie Koło Naukowe STN przy Klinice Anestezjologii i Intensywnej Terapii, Wydział Lekarski z Oddziałem

Lekarsko-Dentystycznym w Zabrzu, Śląski Uniwersytet Medyczny w Katowicach

Kardiochirurgia i Torakochirurgia Polska 2014; 11 (1): 44-47

\begin{abstract}
Background: Ipsilateral shoulder pain (ISP) is a common complication of mixed etiology after thoracic surgery (its prevalence is estimated in the literature at between $42 \%$ and $97 \%$ ). It is severe and resistant to treatment (patients complain of pain despite effective epidural analgesia at the surgical site).

Aim of the study: The aim of this retrospective, observational study was to evaluate the prevalence of ISP in patients operated on in our facility and to determine the risk factors for ISP development.

Material and methods: 68 patients after thoracotomy or videothoracoscopy (video-assisted thoracic surgery - VATS) conducted under general and regional anesthesia were enrolled in the study and divided into two groups: group I without ISP and group II with postoperative ISP. We recorded age, sex, BMI, duration of surgery, type of surgery, type of regional anesthesia, and, in patients with epidural anesthesia, level of catheter placement.

Results: Statistically significant differences between the groups were obtained for BMI (24.67 and 27.68, respectively; $p=0.049$ ), type of surgery $(24 \%$ for thoracotomy and $0 \%$ for VATS, $p=0.026)$, and level of epidural catheter placement (4.35\% for catheters placed at the level of Th5 or higher and $40.47 \%$ for catheters placed below Th5; $p=0.003$ ).

Conclusions: The prevalence of ISP in our medical center amounts to $24 \%$ of thoracotomy patients. The fact that the difference in ISP prevalence was significantly related to the level of epidural catheter placement is consistent with the theory that ISP is related to phrenic nerve innervation. Moreover, epidural catheter placement is a modifiable factor, which can be used to reduce the prevalence of post-thoracotomy ISP. Key words: ISP, thoracotomy, regional anesthesia.
\end{abstract}

\section{Streszczenie}

Wprowadzenie: Tożstronny ból barku (ipsilateral shoulder pain - ISP) po operacjach torakochirurgicznych to częste powikłanie o niejednoznacznej etiologii (częstość określana jest w piśmiennictwie na 42-97\%). Ma znaczne natężenie, występuje pomimo skutecznej blokady zewnątrzoponowej w zakresie miejsca operowanego i jest oporny na leczenie opioidowymi lekami przeciwbólowymi.

Celem pracy była ocena częstości występowania ISP $u$ pacjentów operowanych w naszym ośrodku oraz poszukiwanie ewentualnych czynników ryzyka jego powstawania.

Materiat i metody: Przeprowadzono badanie retrospektywne obserwacyjne populacji 68 pacjentów poddanych zabiegom torakotomii lub wideotorakoskopii przezopłucnowej (video-assisted thoracoscopic surgery - VATS) w znieczuleniu ogólnym i przewodowym. Pacjenci zostali podzieleni na grupy ze względu na występowanie ISP w okresie pooperacyjnym (grupa I - pacjenci, u których nie obserwowano ISP, grupa II - pacjenci z ISP). Oceniano wiek, płeć, współczynnik BMI, czas trwania zabiegu, rodzaj zabiegu, rodzaj znieczulenia przewodowego, a w przypadku znieczulenia zewnątrzoponowego - wysokość założenia cewnika. Wyniki: Znamienne statystycznie różnice pomiędzy grupami I a |l obserwowano dla współczynnika BMI (odpowiednio 24,67 vs $27,68, p=0,049)$, rodzaju zabiegu (24\% torakotomii vs $0 \%$ VATS, $p=0,026)$ oraz pozycji cewnika zewnątrzoponowego (4,35\% dla cewników założonych na wysokości Th5 i powyżej vs 40,47\% dla cewników założonych poniżej Th5, $p=0,003$ ).

Wnioski: Częstość występowania ISP u pacjentów poddanych torakotomii w naszym ośrodku wynosi $24 \%$. Wysokość wprowadzenia cewnika zewnątrzoponowego jako znamienny czynnik powstawania ISP potwierdza teorię bólów rzutowanych z obszaru unerwienia nerwu przeponowego. Jednocześnie jest to czynnik modyfikowalny, mogący stanowić o zmniejszeniu częstości występowania ISP po operacjach torakochirurgicznych.

Słowa kluczowe: tożstronne bóle barku, torakotomia, anestezja regionalna.

Address for correspondence: lek. Maja Copik, Katedra Anestezjologii, Intensywnej Terapii i Medycyny Ratunkowej, Śląski Uniwersytet Medyczny w Katowicach, ul. 3 Maja 13-15, 41-800 Zabrze, Poland, phone: +48 5011366 13, e-mail: maja.grzanka@gmail.com 


\section{Introduction}

Thoracic surgery procedures are associated with significant operative trauma. Many of them are conducted using thoracotomy approaches, classified by procedural guidelines for acute postoperative pain management as procedures associated with significant tissue damage (group III). This entails that the patients undergoing such procedures should be expected to experience pain exceeding 4 points on the Numeric Rating Scale for pain assessment, which can persist for over $72 \mathrm{~h}$ [1]. Methods of managing pain in the surgical area after the said procedures have already been established and well described. However, postoperative ipsilateral shoulder pain after thoracic surgery procedures constitutes a separate problem which is rarely tackled by the literature. Interestingly, the issue pertains to most patients undergoing thoracotomy; its prevalence varies greatly, and has been estimated at between 42 and $97 \%$ by literature reports [2, 3].

Ipsilateral shoulder pain occurring on the operated side in the immediate postoperative period or developing within $2 \mathrm{~h}$ after surgery [4] is most commonly located in the region of the deltoid muscle on the posterior or superior surface of the arm or above $1 / 3$ of the lateral part of the clavicle on the anterior surface of the chest. Patients who suffer from ISP describe it as a dull, stabbing pain of moderate to severe intensity, which is reflected by the Numerical Rating Scale (NRS) for pain assessment, on which ISP often exceeds 7 points. Other ailments may also be present within the same region, including hyperesthesia or even allodynia (a feeling of pain resulting from stimuli which do not provoke pain in healthy persons), hypoesthesia, dysesthesias (unpleasant feelings of pain appearing spontaneously or evoked by a stimulus), and reduced mobility in the area of the shoulder joint. Despite the relatively high prevalence of the described complication, the pathophysiology of its development has yet to be convincingly explained. Medical literature offers several competing theories concerning the causes behind ISP. Some authors postulate that the culprit is the patient's position required by the surgery: the so-called lateral decubitus position, in which the patient lies on the side opposite to the operated one with the ipsilateral upper extremity raised and stabilized on a support (Fig. 1). The resulting additional arcuation of the patient at the level of the scapular angle enables better access to the pleural cavity by widening the intercostal spaces but is also associated with mechanical injuries of shoulder joint ligaments and with pulling on the structures of the brachial plexus [5]. Other suspected causes include the intraoperative irritation or injury of the phrenic nerve [6], pleural irritation or injury in the vicinity of the pericardium, mediastinum, or the diaphragm [4], and main bronchial rupture [2]; the significance of inflammatory [2] and neuropathic [7] factors has also been theorized. The association between ISP and the phrenic nerve appears to be best supported by the evidence gathered so far [6].

Apart from its considerable prevalence, ISP also poses a challenge due to its relatively strong resistance to stan- dard post-thoracotomy treatment - increasing the dosage of epidural analgesia does not yield satisfactory results, nor does the intravenous administration of opioid agents [3]. The methods for managing ISP are varied, which can mostly be explained by the fact that the majority of them depend on the suspected cause of the ailment. They include the intravenous and intramuscular administration of non-steroidal anti-inflammatory drugs (NSAIDs), the administration of preemptive analgesia followed by the continuation of treatment [3], the use of a single loading dose of gabapentin before surgery [7], intrapleural infusions of local analgesics [4], intraoperative injections into the vicinity of the phrenic nerve [6], as well as the use of interscalene brachial plexus block [8] and suprascapular nerve block [5]. The use of opioid analgesic adjuvants as part of a multimodal treatment for postoperative pain has been postulated as well [9].

The aim of this study was to evaluate the prevalence of ipsilateral shoulder pain after thoracic surgery procedures in patients operated on at our center and to determine predictable risk factors for its occurrence.

\section{Material and methods}

This observational retrospective study encompassed 68 patients, including 58 men and 10 women, aged 25 80 years, undergoing thoracic surgery procedures (VATS or thoracotomy) at the Clinic of Thoracic Surgery of the Medical University of Silesia in Katowice between March and May 2009. The data were obtained by analyzing medical archives - medical histories and Acute Pain Service records evaluating the efficacy of the employed analgesic treatment. The patients were divided into 2 groups, depending on the presence of postoperative ISP. Group I encompassed patients in whom no ISP was observed (82\%), while group II was composed of patients with ISP (18\%). The assessment included patient height, body weight, and $\mathrm{BMI}$, the presence of concomitant diseases (diabetes, neuropathy, rheumatoid arthritis), procedure type (video-assisted thoracoscopic surgery or thoracotomy), surgery duration, the type of regional anesthesia, and catheter placement level if epidural block was used. The presence of ipsilateral shoulder pain was evaluated before and after the surgery, at rest and during movement, both before and after the administration of medication. Pain intensity was reflected by numerical scores on the NRS.

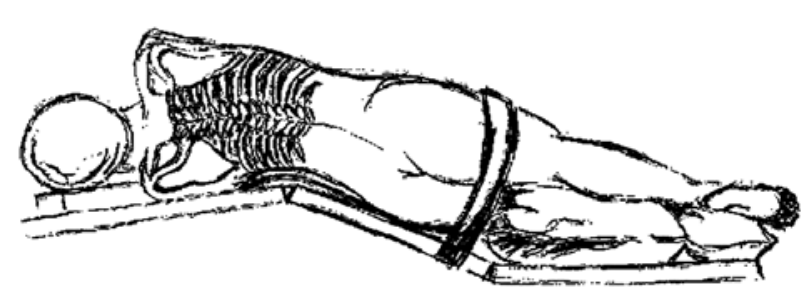

Fig. 1. Patient position for thoracotomy (lateral decubitus position) 
Tab. I. Ipsilateral shoulder pain prevalence and BMI

\begin{tabular}{|c|c|c|c|}
\hline & Group I & Group II & $p$ \\
\hline BMI $\left(\mathrm{kg} / \mathrm{m}^{2}\right)($ mean $\pm \mathrm{SD})$ & $24.67 \pm 4.23$ & $27.68 \pm 5.67$ & 0.049 \\
\hline VATS number of cases [\%] & 17 (100\%) & $0(0 \%)$ & \multirow{2}{*}{0.026} \\
\hline Thoracotomy number of cases [\%] & $38(76 \%)$ & $12(24 \%)$ & \\
\hline
\end{tabular}

$p=0.003$

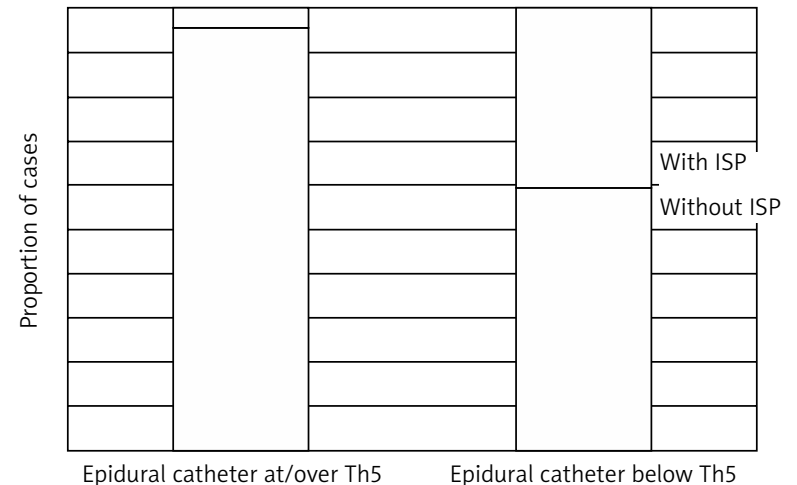

Fig. 2. Ipsilateral shoulder pain prevalence and epidural catheter position

\section{Statistical analysis}

Statistical analysis was conducted with Statistica 10.0 PL software. In order to compare the parameters between the study groups, Student's $t$-test for independent samples was applied to values with a normal distribution. For values with a distribution other than normal, the Mann-Whitney $U$ test was used. Pearson's $\chi^{2}$ test was used to compare the size of the study groups. The results are presented as absolute numbers and percentages, mean and standard deviation. A $p$ value of $<0.05$ was considered statistically significant.

\section{Results}

There was a statistically significant difference between the groups with regard to BMI, which was $24.67 \mathrm{~kg} / \mathrm{m}^{2}$ and $27.68 \mathrm{~kg} / \mathrm{m}^{2}$ in group I and II, respectively (Table I).

The percentage of patients with ISP varied significantly depending on the type of surgery. Among thoracotomy patients, it was $24 \%$, while among patients undergoing video-assisted thoracoscopic surgery it was 0\%. ISP occurred significantly more often in patients with epidural catheters inserted into an intervertebral disc space below Th5 (40.47\%), in comparison to patients in whom the catheter was located at the level of Th5 or higher (4.35\%) (Fig. 2).

In turn, no statistically significant differences were noted between the groups with regard to the remaining parameters.

\section{Discussion}

The goal of this retrospective study was to evaluate the prevalence of ipsilateral shoulder pain after thoracic surgery procedures (VATS or thoracotomy) in the population of patients operated on at our center, as well as to establish the risk factors for ipsilateral shoulder pain occurrence, which have not yet been convincingly determined. The conducted study indicated that, in the general population of patients undergoing thoracic surgery procedures at our center, ipsilateral shoulder pain is relatively rare in comparison with the prevalence of this ailment reported by other authors; however, if only patients undergoing thoracotomy are taken into account, our results are in accordance with other reports. A significantly higher prevalence of ISP was noted among patients with higher $\mathrm{BMI}$, which may corroborate its association with the physical strain and pulling on the shoulder joint ligaments suggested by Tan et al. [5]. The same authors also point to the fact that introducing suprascapular nerve block results in the immediate reduction of ISP intensity in some patients [5] - perhaps increased BMI could allow for the identification of this patient group. Furthermore, a significantly lower prevalence of ISP was demonstrated in patients undergoing thoracotomy under epidural analgesia with catheters introduced at the level of Th5 or higher. This may confirm the reports of some authors, who suggested the existence of a relationship between ipsilateral shoulder pain and pain transmitted via the phrenic nerve and referred to the shoulder [6]. Moreover, the placement of the catheter for continuous epidural analgesia is a modifiable factor; this allows for the achievement of satisfactory results without the need for administering non-steroidal anti-inflammatory drugs, which are associated with a number of side effects [3].

In conclusion, the conducted study has demonstrated that the prevalence of ipsilateral shoulder pain in patients operated on at our center is lower than that reported in the literature and amounts to $24 \%$. What is more, considering the results of this study, it is worthwhile including the following actions in the planning of pain management in patients qualified for planned thoracotomy:

- evaluate BMI, thus determining whether there is an increased risk of postoperative ISP occurrence,

- consider the potential advantages resulting from inserting the catheter for continuous epidural analgesia at the level of Th5 or higher.

One limitation of the presented study is the small size of the examined sample and the method of gathering data - we plan to verify the presented conclusions by conducting a randomized prospective study on a larger group of patients undergoing thoracic surgery procedures. 


\section{References}

1. Misiołek H, Mayzner-Zawadzka E, Dobrogowski J, Wordliczek J. Zalecenia 2011 postępowania w bólu ostrym i pooperacyjnym. Ból 2011; 12: 9-33.

2. Burgess FW, Anderson M, Colonna D, Sborov MJ, Cavanaugh DG. Ipsilateral shoulderpain following thoracic surgery. Anesthesiology 1993; 78: 365-368.

3. Mac TB, Girard F, Chouinard P, Boudreault D, Lafontaine ER, Ruel M, Ferraro P. Acetaminophen decreases early post-thoracotomy ipsilateral shoulder pain in patients with thoracic epidural analgesia: a double-blind placebo-controlled study. J Cardiothorac Vasc Anesth 2005; 19: 475-478.

4. Pennefather SH, Akrofi ME, Kendall JB, Russell GN, Scawn ND. Doubleblind comparison of intrapleural saline and $0.25 \%$ bupivacaine for ipsilateral shoulderpain after thoracotomy in patients receiving thoracic epidural analgesia. Br J Anaesth 2005; 94: 234-238.

5. Tan N, Agnew NM, Scawn ND, Pennefather SH, Chester M, Russell GN. Suprascapular nerve block for ipsilateral shoulder pain after thoracotomy with thoracic epidural analgesia: a double-blind comparison of $0.5 \%$ bupivacaine and 0.9\% saline. Anesth Analg 2002; 94: 199-202.

6. Scawn ND, Pennefather SH, Soorae A, Wang JY, Russell GN. Ipsilateral shoulder pain after thoracotomy with epidural analgesia: the influence of phrenic nerve infiltration with lidocaine. Anesth Analg 2001; 93: 260-264.

7. Huot MP, Chouinard P, Girard F, Ruel M, Lafontaine ER, Ferraro P. Gabapentin does not reduce post-thoracotomy shoulder pain: a randomized, double-blind placebo-controlled study. Can J Anaesth 2008; 55: 337-343.

8. Barak M, laroshevski D, Poppa E, Ben-Nun A, Katz Y. Low-volume interscalene brachial plexus block for post-thoracotomy shoulder pain. J Cardiothorac Vasc Anesth 2007; 21: 554-557.

9. Żukowski M, Kotfis K. The use of opioid adjuvants in perioperative multimodal analgesia. Anaesth Int Ther 2012; 44: 42-46. 